\title{
Resilience-Based Perspectives to Guiding High-Nature-Value Farmland through Socioeconomic Change
}

\author{
Tobias Plieninger $^{1}$ and Claudia Bieling $^{2}$
}

ABSTRACT. Global environmental challenges require approaches that integrate biodiversity conservation, food production, and livelihoods at landscape scales. We reviewed the approach of conserving biodiversity on "high-nature-value" (HNV) farmland, covering 75 million ha in Europe, from a resilience perspective. Despite growing recognition in natural resource policies, many HNV farmlands have vanished, and the remaining ones are vulnerable to socioeconomic changes. Using landscapelevel cases across Europe, we considered the following social-ecological system properties and components and their integration into HNV farmland management: (1) coupling of social and ecological systems, (2) key variables, (3) adaptive cycles, (4) regime shifts, (5) cascading effects, (6) ecosystem stewardship and collaboration, (7) social capital, and (8) traditional ecological knowledge. We argue that previous conservation efforts for HNV farmland have focused too much on static, isolated, and monosectoral conservation strategies, and that stimulation of resilience and adaptation is essential for guiding HNV farmland through rapid change.

Key Words: agricultural landscapes; agricultural management; ecosystem stewardship; Europe; farmland habitats; landscape change; resilience framework

\section{INTRODUCTION}

More than $75 \%$ of the world's ecosystems show evidence of alteration through human activities (Ellis and Ramankutty 2008), and land use activities have threatened and degraded ecosystems and their functioning worldwide (Millennium Ecosystem Assessment 2005). Here, we highlight a less antagonistic, and often neglected, dimension of the relationship between land and people: the crafting of landscapes with a distinctly human touch through complex and long-lasting land use histories that have intimately connected social and ecological values (Farina 2000, Takeuchi 2010). Recently, the idea that landscapes can effectively integrate ecology, economics, and cultural needs has gained ground in science, policy, and land use practice. For example, a global "Landscapes for People, Food and Nature" initiative, a partnership of the United Nations Environment Programme, the Food and Agriculture Organization of the United Nations, and other global organizations, currently seeks to integrate food production, biodiversity and ecosystem conservation, and rural livelihoods within supportive institutional and policy contexts under an "ecoagriculture" framework (Scherr and McNeely 2008). Challenges such as climate change, environmental degradation, and rising food demand are likely to require integrated landscape approaches even more so than in the past because conventional high-input agriculture has transgressed the boundaries of sustainable production (Tscharntke et al. 2012). In Europe, awareness of the fact that many of the continent's most appreciated habitats and plant and animal species have been created and maintained by farmers and their practices has grown since the 1990s (Baldock and Beaufoy 1993, Beaufoy et al. 1994, Bignal and
McCracken 1996), leading to the development of the notion of "high-nature-value" (HNV) farming (Oppermann et al. 2012). The resilience school, a research community revolving around "the capacity of a system to experience shocks while retaining essentially the same function, structure, feedbacks and therefore identity" (Walker et al. 2006), has successfully established guiding principles for a broad range of sectors in natural resource management (Chapin et al. 2009). However, widely applicable strategies for fostering resilience in HNV farmland have not been assessed yet. We have reviewed selected European cases (Fig. 1) and synthesized insights into the vulnerability and resilience of HNV farmlands. We argue that previous conservation efforts for HNV farmland have focused too much on static, isolated, and monosectoral conservation strategies, and that emphasis on resilience and adaptation is essential for guiding HNV farmland through rapid economic and social change.

\section{HNV FARMLAND}

According to a definition by Andersen et al. (2003:4), HNV farmland comprises "those areas in Europe where agriculture is a major (usually the dominant) land use and where that agriculture supports or is associated with either a high species and habitat diversity or the presence of species of European conservation concern or both." HNV farmland accommodates habitats both on cultivated or grazed areas and in features such as hedgerows, ponds, and trees, which were historically integrated into farmlands. In Europe, these are of particular conservation importance because large-scale natural habitats have virtually disappeared (Halada et al. 2011). The HNV concept is a conservation approach that links the domains of 
Fig. 1. HNV (high-nature-value) farmlands considered as case studies in this review. Boxes indicate study area, country, extent, and ecological systems in focus.

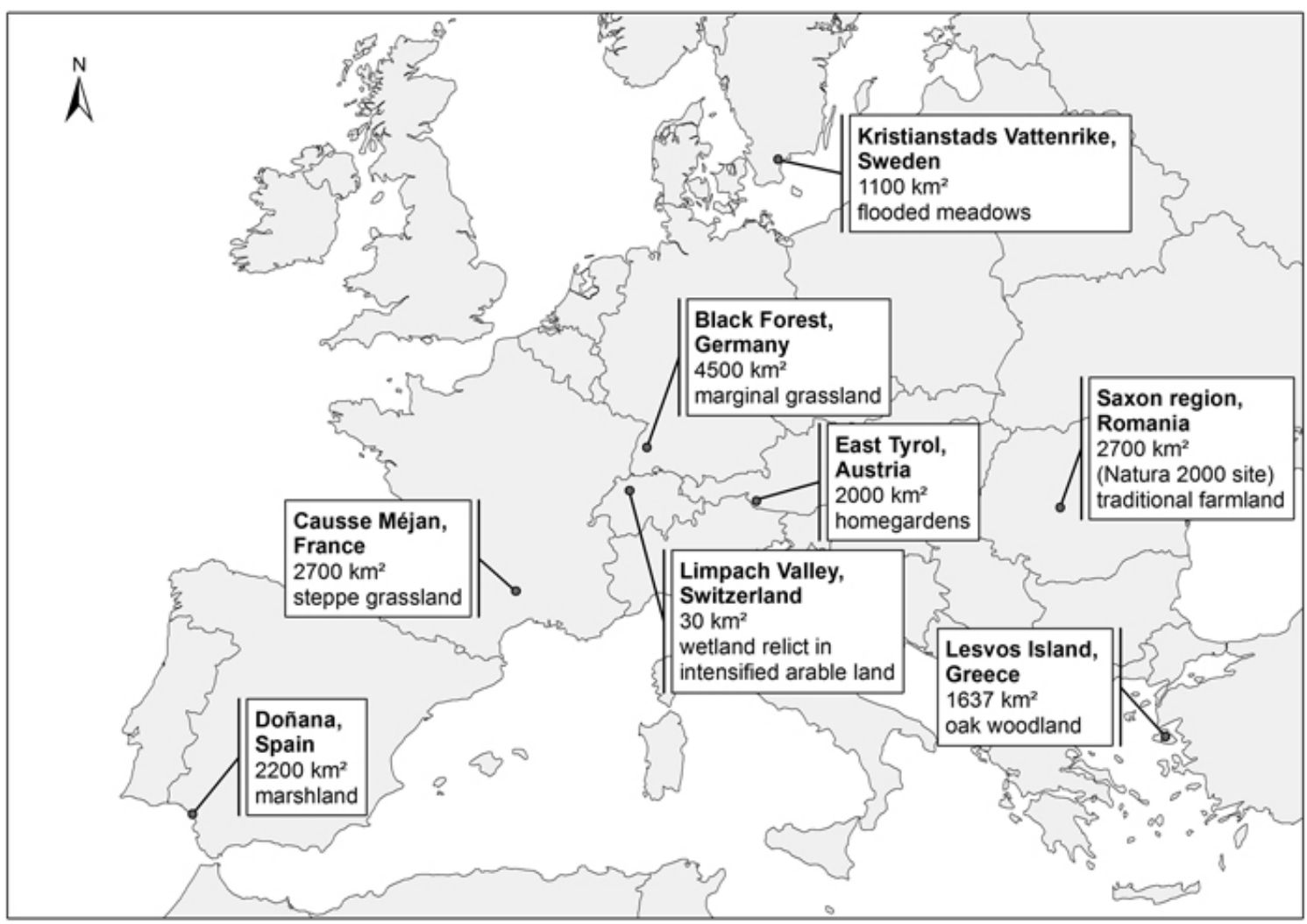

ecology, land use, and public policies, expanding conservation from traditional site protection to the scale of managed landscapes. The HNV concept refers both to farmlands and farming systems. These terms show overlap but are not congruent (Cooper et al. 2007). We use "farmland" for land suitable or used for all kinds of agricultural activities. "Farming systems" are sets of individual farms that have broadly similar resource bases and constraints and transform land, labor, and capital into agricultural commodities. Farmlands and farming systems are closely connected to each other. Key characteristics of HNV farmland are low-intensity practices, in terms of fertilizer and pesticide inputs, machinery, and livestock stocking levels used; the presence of seminatural vegetation, e.g., unimproved pastures; and diversity of land cover, e.g., crops, fallow land, pasture, and landscape elements (Fig. 2). The presence of, sometimes relictic, sometimes abundant, remnants of natural vegetation, e.g., woodland patches, that provide habitats and connectivity for animal assemblages is another important component of HNV farmland (Farina 2000).
Fig. 2. Key characteristics of HNV (high-nature-value) farming. Reproduced from Cooper et al. (2007).

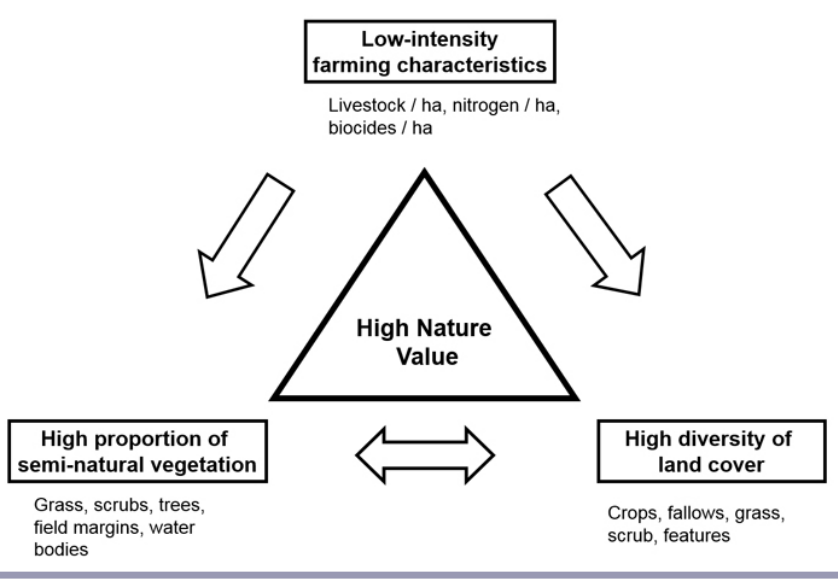


Fig. 3. Likelihood of presence of HNV (high-nature-value) farmland across the European Union. Reproduced from European Environment Agency (2010).

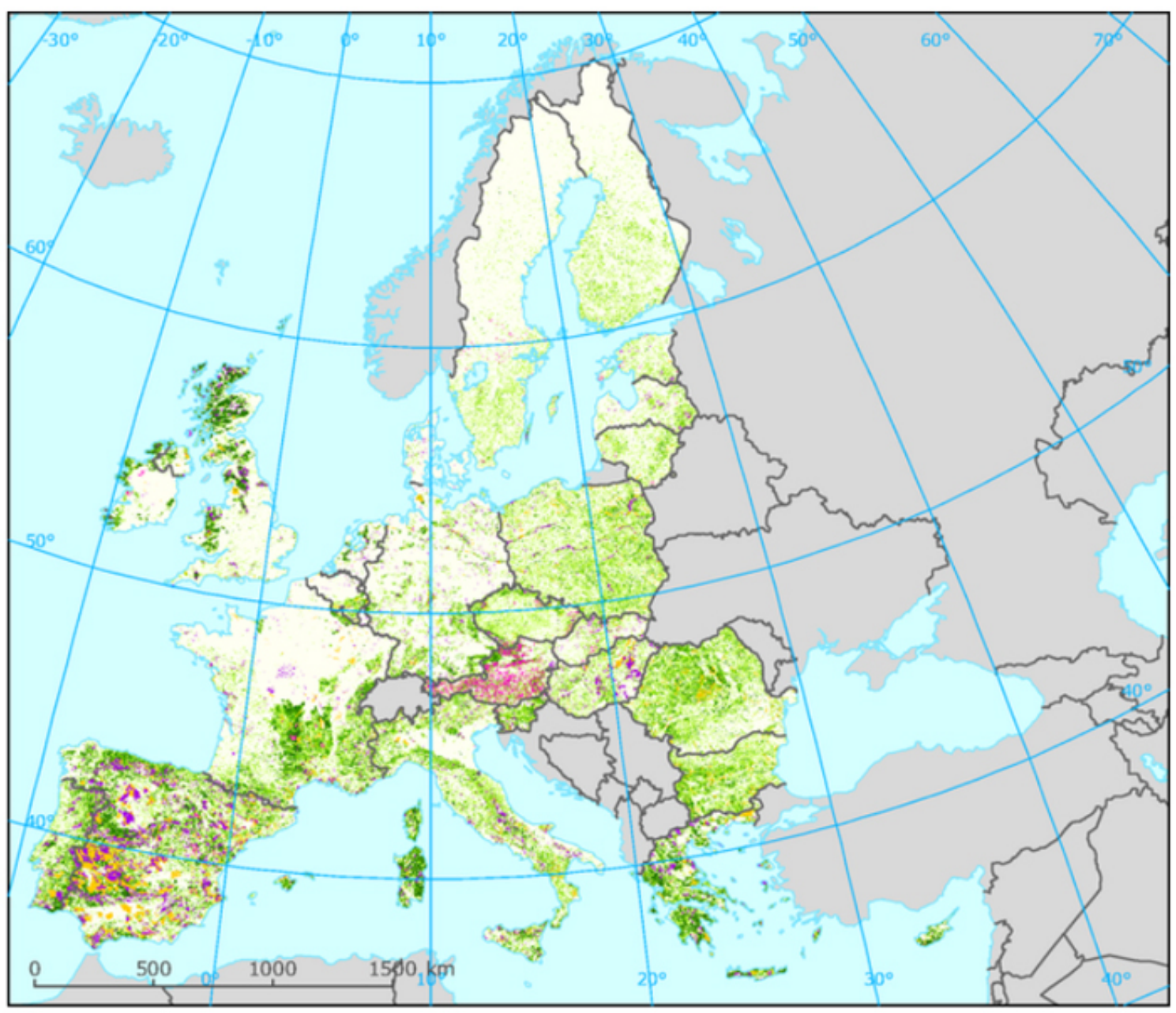

\section{Approximate distribution of High Nature Value (HNV) farmland across Europe}

\section{Nature 2000 sites}

Prime butterfly areas (PBAs)

Important bird areas (IBAs)
HNV farmland \%

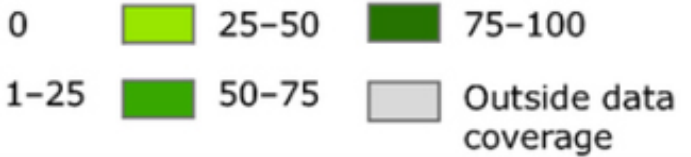

Although the characteristics of HNV farmlands are likely to apply to other areas in the world as well, the concept specifically refers to Europe. HNV farmlands occur in a variety of environments, climatic conditions, economic contexts, and production systems (Fig. 3), covering about $32 \%$ (75 million ha) of the European Union (EU) farmland (Paracchini et al. 2008). HNV systems are classified into livestock systems, arable systems, and permanent cropping systems. Typical HNV farmlands are traditionally managed hay meadows, small-scale mosaics of cultivated land, traditional orchards, and low-intensity olive groves (Fig. 4). HNV farmland tends to be concentrated in the Mediterranean Basin, Eastern Europe, upland areas, and on the margins of northwestern Europe (Cooper et al. 2007).

A characteristic feature of HNV farmland is that multiple and long-term management techniques contribute toward enhancing the structural diversity of vegetation $\left(\mathrm{O}^{\prime}\right.$ Rourke and 
Fig. 4. Examples of typical HNV (high-nature-value) land-use systems in Europe (from upper left to lower right): a) Traditional hay meadows and pastures in the Saxony region of Romania; b) Low-intensity, small-scale farming/grazing in Castilla-La Mancha, Spain; c) Traditional orchards with permanent seminatural understory in Southern Germany; d) Mediterranean dryland olive crops on Lesvos Island, Greece. Courtesy of Tibor Hartel (a), Berta Martín López (b), Ursel Maichle-Schmitt (c), and Thanasis Kizos (d).
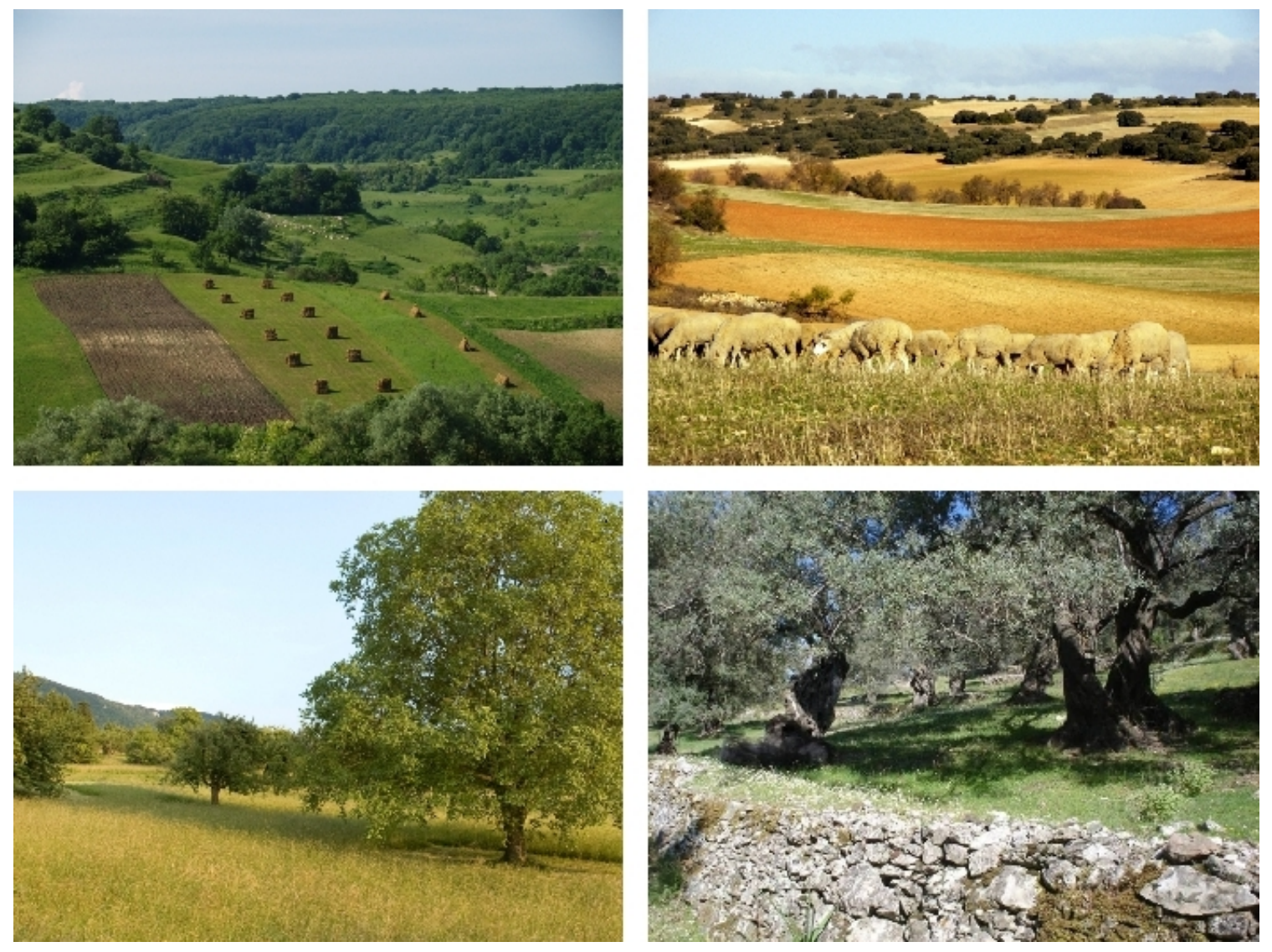

Kramm 2012). This has translated into land-cover mosaics and diverse habitats beneficial to many birds (Fig. 5) and invertebrates. In consequence, much of Europe's biodiversity, including species of global conservation concern, such as the Corn Crake (Crex crex; Tucker and Heath 1994), is found on such farmland (Bignal and McCracken 1996). However, some farmlands do not show these characteristics but support certain species of conservation concern nevertheless. Examples are intensively managed damp and wet grasslands in the Netherlands that are favored by the Black-tailed Godwit (Limosa limosa) or large-scale cereal steppes in Iberia that host substantial populations of the Great Bustard (Otis tarda; Oppermann et al. 2012). Many HNV farmlands are closely associated with wild species and natural habitats. For example, a total of 63 (out of 231) habitat types of European conservation interest depend on the long-term continuity of HNV farmland management for their existence (Halada et al.
2011). Also, HNV farmlands provide habitat to more at-risk species than any other habitat type in Europe (Johnson et al. 2011). HNV farming also results in multiple ecosystem services, comprising provisioning, e.g., high-quality food and maintenance of genetic resources; regulating, e.g., soil quality regulation, pollination, and water purification; and cultural, e. g., heritage, recreation, and ecotourism, services (Oppermann et al. 2012).

\section{VULNERABILITY OF HNV FARMLAND}

Despite the growing recognition that conservation of biodiversity in Europe depends on the maintenance of HNV farming, many of these systems are vulnerable to global economic and social change (Jansen et al. 2009). For several decades, trends of agricultural modernization, including, e.g., a shift from local to globalized markets, availability of and higher wages for off-farm jobs, mechanization, and 
Fig. 5. Bird species of European conservation concern that are indicative of HNV (high-nature-value) farmland (from upper left to lower right): a) Common Crane (Grus grus), b) Eurasian Hoopoe (Upupa epops), c) Red-backed Shrike (Lanius collurio), d) Great Bustard (Otis tarda). Courtesy of Jörg Mager (a), Hans Dekker (b), Urska Koce (c), and Arie de Knijff (d).
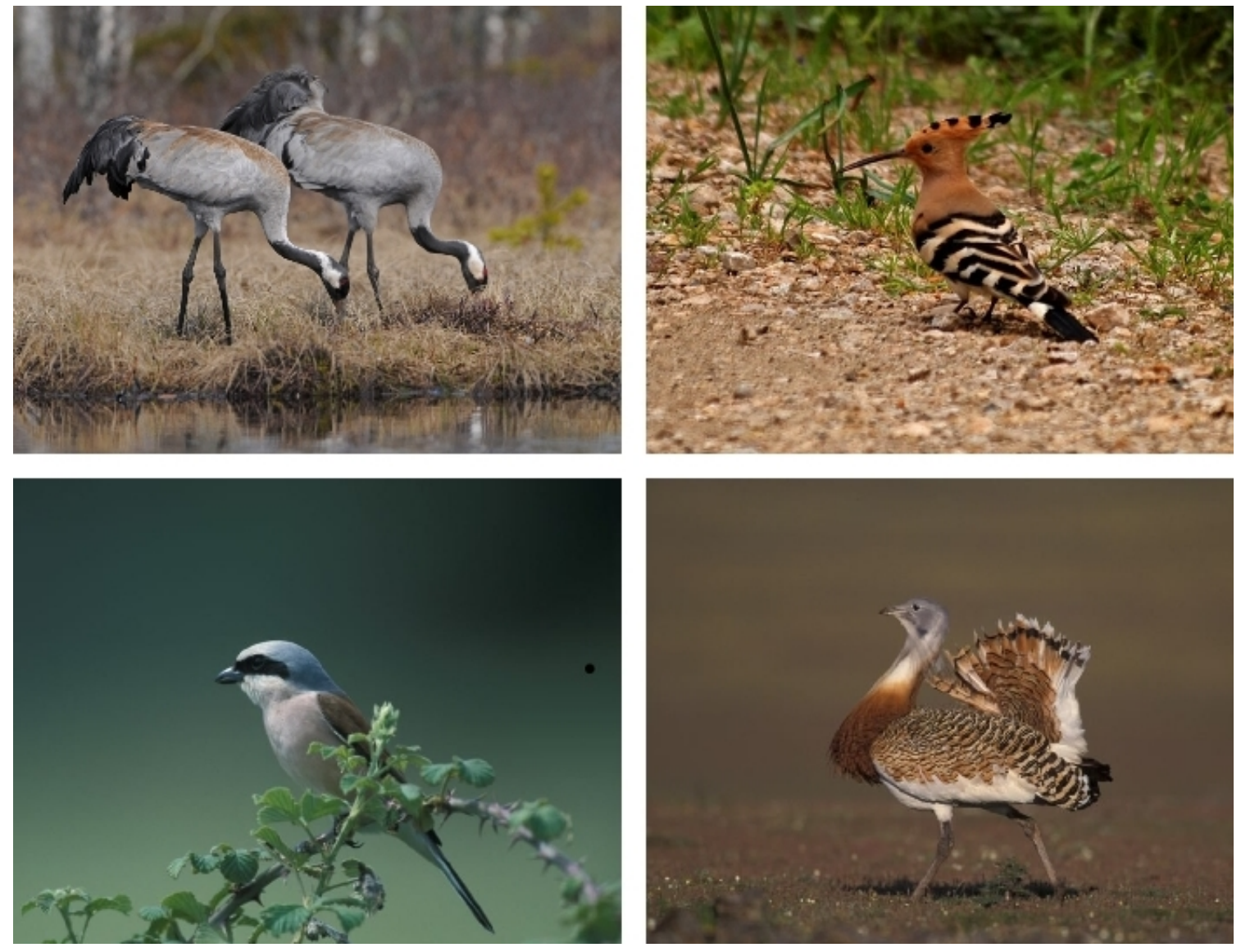

individualization of family structures, have induced profound changes in land use practices and put HNV farming under pressure. In consequence, HNV farming systems have vanished from many productive areas of Europe so that most agricultural habitats are currently in an unfavorable conservation status (Halada et al. 2011). As a result of the vanishing of $\mathrm{HNV}$ practices, European farmland bird populations have declined by almost 50\% since the 1970s (Butler et al. 2007). HNV farming systems are today concentrated in areas that are only marginally suitable for commercial agriculture, generally because of physical constraints, soils, topography, climate, and remoteness (Oppermann et al. 2012). The financial revenues of HNV farming systems are thus generally lower than those of other, more intensive agricultural systems. Sometimes HNV farms have negative net incomes and are sustained by family labor less than the minimum wage. The remaining HNV systems are at risk of being converted to more intensive forms of agriculture, which would involve clearing of seminatural vegetation and loss of land use mosaics. Alternatively, farmers may abandon their land, e.g., after retirement (Verburg et al. 2010). Large areas have been afforested in the past, often accompanied by losses of biodiversity, landscape, and sociocultural values, as well as increasing wildfire problems (MacDonald et al. 2000). However, it has recently been argued that land abandonment may open up opportunities for rewilding ecosystems (Navarro and Pereira 2012), if risk and propagation of wildfires can be managed and if seed banks, neighboring natural vegetation, and connectivity of a landscape provide potential for "passive restoration."

The HNV concept reflects efforts within the EU to secure sustainable rural development by stimulating land stewardship, rather than pure production agriculture. In 2006, the EU strategic guidelines for rural development declared "the preservation and development of HNV farming and forestry systems and traditional agricultural landscapes" as 
one of three EU-level priority areas for protecting and enhancing the EU's natural resources and landscapes in rural areas (EU 2006:25). The support and maintenance of HNV landscapes has, however, proved to be complicated, and a fundamental shift in agricultural policies away from intensive farming and toward providing support for HNV farming and connected ecosystem services has not yet occurred. One reason for the failure of the EU Common Agricultural Policy to provide sufficient economic support for HNV farming systems is that the so-called First Pillar market support schemes lack mechanisms that link payments to specific EU policy objectives such as the preservation and development of HNV farming and forestry systems. Typically, HNV farmlands receive below-average First Pillar payments (Beaufoy and Marsden 2013). Also, the impact of the so-called Second Pillar schemes, which comprise rural development policies, including agri-environment measures, has so far remained modest (O'Rourke and Kramm 2012). This is not surprising, given that the financial endowment of agri-environment schemes has remained low, amounting to only $4.3 \%$ of the total EU agricultural budget in 2008 (Plieninger et al. 2012), and that these are overburdened with multiple environmental issues. Ironically, the lowest agri-environment expenditure is often found in regions with the largest concentrations of HNV farmland. Another problem is that there are currently no measures explicitly directed to $\mathrm{HNV}$ farming practices (Beaufoy and Marsden 2013). Design issues of existing schemes, such as considerable transaction costs for farmers, further weaken the performance of agri-environment schemes (cf. Schleyer and Plieninger 2011). Clearly, new visions to ensure the sustainability of HNV farmlands are needed, channeling unavoidable changes in ways that can maintain the biodiversity and ecosystem services provided by $\mathrm{HNV}$ farming.

\section{RESILIENCE AS A FRAMEWORK FOR ANALYZING AND MANAGING CHANGES IN HNV FARMLAND}

The resilience approach focuses on the dynamics of change and how to adapt to and shape change (Walker et al. 2006). It offers both concepts for analysis of a system and guidelines for directing it along desired pathways, that is, ideas for the understanding and management of change in social-ecological systems. The concept, therefore, addresses questions that are of crucial significance for valuable HNV farmland and farming systems with their high vulnerability to current global social and ecological changes. From the resilience perspective, landscapes are capable of coping with disturbances, e.g., demographic or economic changes, without changing their structure or functions, until they cross certain thresholds. However, such thresholds have not been systematically investigated for HNV farming yet. Beyond these thresholds, disturbances cannot be cushioned anymore and the system shifts to a different state, e.g., marginal grassland is abandoned and turns into forest, often accompanied by a degradation or narrowing down of ecosystem services. Resilience thinking can address the fluid and unfixed character of landscapes, a result of complex and closely interwoven natural and human processes, particularly well (Plieninger and Bieling 2012). We analyzed the persistence and decline of HNV farmland through the lens of resilience. Using examples from Europe, we considered the following eight social-ecological system properties and components and their integration into HNV farmland management: (1) coupling of social and ecological systems, (2) key variables, (3) adaptive cycles, (4) regime shifts, (5) cascading effects, (6) ecosystem stewardship and collaboration, (7) social capital, and (8) traditional ecological knowledge.

\section{Social and ecological systems need stronger recoupling through "virtuous circles"}

Resilience thinking assumes that the interactions between social and ecological subsystems determine the inner structures and functional organization of social-ecological systems (Liu et al. 2007). Fischer et al. (2012) conceptualized an HNV farming landscape in Romania's Saxony region as a social-ecological system in which the ecological and social subsystems have been tightly linked historically because people have shaped the land through their activities and the land has provided people with a variety of ecosystem services. Traditionally, cultural identity has been deeply rooted in the landscape. Since the collapse of Communism in 1989, however, subsistence agriculture has become unprofitable, and livestock numbers and grassland area have declined sharply. Poverty and unemployment increased after the closure of state farms, and people were decoupled from their farm landscapes. The standard conservation approach in Europe has been to pay farmers for maintaining traditional farming practices, e.g., through agri-environmental schemes. However, attempting to conserve past land use systems through financial incentives cannot restore the intricate cultural linkages between people and their landscape (Daniel et al. 2012). Rather, a "transformation strategy" could reinstate contemporary and thus more meaningful "virtuous circles" between sources of natural, cultural, and economic capital within landscapes (Selman and Knight 2006). Such a strategy, whose positive effects still remain to be assessed comprehensively, may include developing markets for organic or regional specialty products, ecotourism, and localized production of biomass energy. All over Europe, rising consumer demand for traditional high-quality food has to some extent awakened citizen engagement for HNV landscapes (for example, Knickel 2001).

\section{A few key variables critically determine landscape change}

Alterations in the state of a landscape depend on a small number of key variables that are often assumed to develop only gradually over years but that exert strong influences on the resilience of a system (Chapin et al. 2009). Key variables 
are influential, acting at spatial, temporal, and institutional scales, and include the following: socioeconomic, political, technological, natural, and cultural driving forces (Hersperger and Bürgi 2009). A case study of land use change in the Swiss Limpach valley by Bürgi et al. (2010) illustrates how awareness of key variables can enable understanding of the trajectories of HNV landscape elements. The historical landscape analysis of a seemingly persistent wetland in the area has revealed profound land use changes. Because of its massive layer of peat, a combustible that was in high demand during World War II, the wetland took a different course from its surroundings, which were completely converted from pasture to arable land. During World War II, the wetland was excluded from being converted to arable land, and instead, its valuable peat layer was mined. Peat mining was later abandoned, and the area developed into a wetland of HNV, which is currently a nature reserve. With observations of approximately 190 plant species and more than 150 bird species, the area is now listed on the Federal Inventory of Fenlands and is recognized as a particularly important place for migrant waders. In the Limpach valley case, wartime energy policies, not conservation policies, were the key variables, and by virtue of this the most important drivers, of wetland conservation. Therefore, the case highlights the importance of a broad cross-sectoral perspective, which reaches outside the agricultural and conservation domains, to be able to identify the key variables that govern the trajectories of HNV farmland.

\section{Many HNV landscapes are in a late conservation phase of the adaptive cycle and about to collapse}

Processes of change in social-ecological systems follow specific patterns, with the adaptive cycle being a generalized model of thought in resilience theory (Holling 1973). This metaphor describes a slow, incremental phase of growth, accumulation, and conservation, e.g., of biomass or social capital, followed by a rapid phase of collapse, reorganization, and renewal. This latter phase is marked by uncertainty, novelty, and experimentation and may end either in destructive or creative change in the system. Many HNV landscapes can be associated with a late conservation phase, approaching the collapse phase. For instance, HNV grassland created by longterm pastoralism is increasingly being abandoned in the Black Forest mountain range in southern Germany, whereas closed forests are expanding (Bieling 2013). Traditional HNV grassland in this area harbors high levels of endangered species of birds and plants and provides important cultural ecosystem services. Since the 1980s, the biodiversity and ecosystem services supported on these lands have been increasingly appreciated by society, but it has been challenging to translate this appreciation into tangible conservation measures. In such a situation, resilience-based approaches foster site-specific incentives for self-organization and renewal, rather than aiming to simply maintain the status quo of grassland extent and management. Potential measures to address agricultural abandonment in the Black Forest include adapting regulations and funding schemes to the particular conditions of the socialecological system in question and opening up opportunities for locally based action. It should be acknowledged, however, that financial incentives alone will not be helpful as long as a basic local engagement is not a given. It has been shown that heterogeneous community identities require diversified and locally adapted management strategies that are, taken together, more successful than standardized approaches. One such example is a group of local activists that organized the clearing of already reforested lands in one Black Forest community. These lands were supposed to be subsequently grazed by a herd of goats to reinvent local pastoralism. This initiative proved successful in preserving HNV grassland. Its success was built on the ability to open up diverse ways for local people, but also for external enterprises and policy makers, to get involved. In addition, the initiative made smart use of existing options to support funding and organization. This example underlines the resilience need for embracing diversity and fostering social capital at community levels, especially in times of renewal.

\section{HNV landscapes experience regime shifts that are hard to reverse}

Many relationships between the components of HNV farming systems are not linear, but rather shaped by critical thresholds that define transition points between alternate states (Chapin et al. 2009). Typically, incremental changes in ecosystem conditions lead to the crossing of a threshold, causing large shifts in the system, often from desirable to less desirable states. In this course, the fundamental internal controls and feedbacks are altered in such a way that the reversibility of the system to its original state is very limited (Scheffer and Carpenter 2003). One local-level example is the case of the Valonia oak (Quercus macrolepis) woodlands on the Aegean Islands of Greece, which experienced a comprehensive shift from a once complex agrosilvopastoral land use regime to a now simplified and intensified form of livestock husbandry (Plieninger et al. 2011). A critical threshold was crossed in the 1960s and 1970s, when the opening of local cereal markets to competition from more productive areas made traditional cultivation unprofitable. At the same time, increased nationwide demand for dairy and meat products provided a powerful incentive for intensified livestock raising. The oak woodland system came out of this regime shift with an altered identity and functioning: Most farm enterprises were no longer self-sufficient and became dependent on supplementary feed, fertilizer, and agrochemical inputs. As crop cultivation and forest management were abandoned, the former mosaic landscape of arable land, stone terraces, tree crops, and pastures was replaced by a simplified and more homogeneous landscape of intensively grazed rangelands with scattered oaks. Moreover, the regime shift was reinforced by European 
policies that granted per capita subsidies for sheep and goats. The new regime of intensified livestock production has proved unlikely to be reversed, with stocking rates remaining high despite European policies having been reformed and the demand for dairy and meat products now being satisfied by cheaper imports. Similar regime shifts away from traditionally multifunctional land use systems have been found throughout a variety of landscapes in the Mediterranean Basin. Examples include the Mediterranean mountains that were stamped by pastoralism, including transhumance; the small-scale hamlet landscapes of northeastern Portugal with their complex irrigated meadows, or lameiros; the coltura promiscua landscapes, or mosaics of mixed cultures on terraces, in central Italy; the chestnut-grove landscapes in France and Italy; and the dehesa and montado agroforestry systems of the Iberian Peninsula (Pinto-Correia and Vos 2004). Practical solutions to avoid undesired regime shifts require the identification of critical points for management interventions both in the ecological and socioeconomic spheres of a landscape, which are largely unknown. This calls for interdisciplinary integration, particularly regarding the development of indicators that are suitable for monitoring state shifts in landscapes (Gee and Burkhard 2012). Scenario development, visioning exercises, and other participatory tools (Lynam et al. 2007) may foster awareness of regime shifts among landscape actors.

\section{HNV landscape changes imply cascading effects across several scales and domains}

Regime shifts not only occur for single variables and thresholds, but are also typically connected across several spatial and temporal scales, termed "panarchy" in the resilience framework (Gunderson and Holling 2002). Additional complex feedback exists between cultural, economic, and ecological domains, often involving cascading effects through which the crossing of one threshold spurs the crossing of others. Important cascading effects of landscape change were found in the Causse Méjan, a biosphere reserve in the French Massif Central. This elevated limestone plateau is characterized by steppe grasslands with an elevated level of farmland biodiversity. Socioeconomic and political changes affected land use practices, and the area experienced a strong trend toward woodland expansion, leading to losses in biodiversity (O'Rourke 2006). Kinzig et al. (2006) analyzed the processes in detail for different scales, e.g., patch, farm, and region; and domains, e.g., ecological, economic, and cultural. They described a range of effects that cascade across the domains and scales. For instance, when several patches on a farm revert to woodland, the farmer may completely abandon cheese production because the milk produced may no longer be worthwhile for the maintenance of necessary technical infrastructure. As this example demonstrates, a threshold crossed at the patch level in the ecological domain may cause a socioeconomic shift at the farm level. Therefore, because switches between different scales and domains are typical for social-ecological systems, concentrating on thresholds in a single domain or at a single scale is likely to lead to deficiencies in the analysis and management of changing HNV landscapes. This is particularly relevant for landscapes because current policies do not address them in a holistic way, but with a multitude of separate strategies for agriculture, forestry, biodiversity conservation, rural development, infrastructure, health, and many others. Developing and implementing strategies that integrate across domains and scales, the necessity of which has been emphasized in the European Landscape Convention (COE 2000), is thus a most challenging and necessary task.

\section{Ecosystem stewardship and collaboration are crucial for adaptive landscape management}

Adaptive management, i.e., "resource management based on the science of learning by doing" (Chapin et al. 2009:78), is a core component of resilient HNV farmland management. A recent Pan-European evaluation has provided empirical evidence that biodiversity and ecosystem services are most effectively safeguarded through consideration of the perspectives of local ecosystem stewards (Kenward et al. 2011). Ecosystem stewards are individuals or groups that exert influence on ecosystems and their goods and services at the local scale (Chapin et al. 2009). In the EU, professional land users are complemented by up to 100 million recreational ecosystem stewards, including approximately 24 million anglers, 7 million hunters, and 7 million birdwatchers (Kenward and Sharp 2008). An inventory of ecosystem stewards was performed in the Kristianstads Vattenrike area in southern Sweden (Schultz et al. 2007). Several hundred stewards managed ecosystems on-site, performed long-term monitoring of species and ecosystem dynamics, and supported ecosystem management locally. Biodiversity and ecosystem services are frequently provided at scales beyond those of single patches or farms, so cross-scale coordination of ecosystem stewardship is of major importance (Olsson et al. 2007). Potential levers for fostering ecosystem stewardship at the landscape-scale are agri-environmental schemes (Prager and Freese 2009), landscape management initiatives (Enengel et al. 2011), and landscape planning (Termorshuizen and Opdam 2009). Such efforts should particularly address bridging organizations, e.g., land care groups, which are essential for providing leadership and vision, supporting knowledge networks, and maintaining the link between culture and management at landscape scales (Crona and Parker 2012).

\section{Social capital connected to HNV farming systems is an important source of resilience}

Many HNV land use practices exhibit characteristics that the resilience framework identifies as indicators of resilienceoriented management (Folke et al. 2002), including the following: learning to live with change and uncertainty by continuous adaptation to changing conditions, nurturing 
diversity as a prerequisite for reorganization and renewal, combining different kinds of knowledge, and creating opportunities for self-organization by, for example, fostering multioption strategies. Many of these practices are embedded in diverse social mechanisms and aims. For instance, home gardens that are intrinsically linked into surrounding HNV farmland and local culture in the Austrian Alps provide secure access to food, medicine, or ornamental and ritual plants and act as a buffer for overcoming economic disturbances, in past as well as current times. They also foster social capital, e.g., trust, reciprocity, and community networks, through exchange of knowledge and gift giving of, for example, surplus plant material (Van der Stege et al. 2012). Home gardening practices involve a large number of resources and strategies, with flexibility and continuous adaptation to change as core features of their composition and management. In the Austrian home gardens case, and likewise demonstrated, for example, in urban gardens in Stockholm (Barthel et al. 2010), social capital creates highly resilient small agroecosystems that add to the resilience of the broader landscape context, e.g., by providing critical ecosystem services such as pollination, seed dispersal, or pest regulation. Therefore, integrating and fostering social capital should be acknowledged as a crucial component of sustainable rural development incentives. This can be achieved, for instance, by nurturing the social-ecological memory related to landscape practices, by supporting social networks and community-based action, or by creative approaches such as art performances that foster the engagement of people with place.

\section{Traditional ecological knowledge fosters long-term landscape resilience}

"Traditional ecological knowledge" and "local ecological knowledge" increase the capacity of social-ecological systems to deal with crises and to maintain long-term resilience (Berkes et al. 2000). It has been frequently demonstrated that traditional ecological knowledge is critical to the survival and future well-being of traditional societies worldwide (Huntington 2000, Folke 2004). Although there is less available evidence on the role of this knowledge in developed countries (Parrotta and Agnoletti 2007), the role of traditional knowledge for building social-ecological resilience has been studied in 13 rural communities in the Doñana landscape of southwestern Spain (Gómez-Baggethun et al. 2012). Doñana contains highly diverse and well-preserved ecosystems and represents one of the most emblematic wetlands in Europe. To cope with environmental change and climatic variability, above all the unpredictable occurrence of droughts, landscape users have developed locally adapted practices and institutions throughout history. Examples include periodic movements, e. g., of livestock, to minimize exposure to risks and environmental hazards; selection of species and varieties adapted to local environmental conditions; regular adjustment of harvesting intensity to suit ecological productivity; pooling of resources, infrastructures, and labor among resource users; and diversification of income, sources, and skills to spread out disturbance-related risks. However, traditional ecological knowledge has been or is being lost across generations in many parts of Europe (Rotherham 2007), often because of rapid transformations and modernization of land use systems. There is some evidence that transmission of traditional ecological knowledge may be aligned with modernizing influences through strengthening farming systems with strong links to cultural identity, such as traditional livestock husbandry (Gómez-Baggethun et al. 2010). The Doñana study highlights the need for new management and governance approaches that capitalize on localized, traditional ecological knowledge. Such knowledge is particularly useful to facilitate collective responses to the ecological and socioeconomic dynamics that many HNV landscapes are facing. To support these approaches at a higher level, strategic efforts are needed to mainstream traditional ecological knowledge into environmental policy processes such as the nascent Intergovernmental Platform on Biodiversity and Ecosystem Services (Hernández-Morcillo et al. 2014).

\section{CONCLUSIONS}

Europe's remaining HNV farmlands face numerous socialecological changes, with powerful economic drivers putting their persistence at risk. As public recognition of their manifold value grows, strategies for their conservation are therefore much needed. However, conventional policies, split up in several separate fields, such as heritage, environmental conservation, or agricultural policies, have not been effective at conserving HNV systems (Matthews and Selman 2006).

The case studies we reviewed exemplify that the resilience perspective allows actors at the policy and management level to refocus attention on critical properties and variables of HNV farmland, which is a prerequisite for formulating successful strategies to maintain HNV farmland and its inherent values. We identified eight resilience-based strategies that may be particularly useful in this regard (see summary in Table 1). Some of these concepts, strategies, and examples provide new insights; others may not be completely new for the farmland conservation community. However, to our knowledge, they have not been put together into a coherent conservation strategy, and they are hardly visible in the implementation of management and policies for HNV farmland up to this point. For the conservation of HNV farmland, standardized and monosectoral command-and-control policies are increasingly unhelpful. They need to be replaced by integrated approaches that deliberately include humans and their activities, take into account the full suite of HNV landscape multifunctionality, and allow for locally defined and adapted strategies (Rescia et al. 2010). Moreover, understanding and awareness of the critical variables driving HNV landscapes have to be enhanced in the course of extended monitoring systems and approaches fostering a broad public engagement with looming 
Table 1. Strategies to maintain HNV (high-nature-value) farmland as derived from eight components of the resilience framework.

\begin{tabular}{|c|c|c|}
\hline Concept & Strategy & Examples \\
\hline $\begin{array}{l}\text { Coupling of social and } \\
\text { ecological systems }\end{array}$ & $\begin{array}{l}\text { Include humans and their current activities as active } \\
\text { components of HNV landscapes and support the full suite } \\
\text { of landscape multifunctionality }\end{array}$ & $\begin{array}{l}\text { Developing markets for organic or regional } \\
\text { specialty products, ecotourism, and localized } \\
\text { production of biomass energy }\end{array}$ \\
\hline Key variables & $\begin{array}{l}\text { Identify critical variables that govern HNV farmlands } \\
\text { across a broad range of spheres }\end{array}$ & $\begin{array}{l}\text { Considering variables external to HNV } \\
\text { farmland such as energy policies or } \\
\text { demographic structure of local population }\end{array}$ \\
\hline $\begin{array}{l}\text { Late conservation phase / } \\
\text { adaptive cycles }\end{array}$ & $\begin{array}{l}\text { Move away from standardized command-and-control } \\
\text { solutions and embrace the specificities of HNV farmland } \\
\text { across space and time }\end{array}$ & $\begin{array}{l}\text { Allowing locally defined and adapted strategies } \\
\text { in regulations and funding schemes }\end{array}$ \\
\hline Regime shifts & $\begin{array}{l}\text { Create prerequisites for fostering stabilizing feedbacks to } \\
\text { avoid shifting ecosystems toward an undesirable state }\end{array}$ & $\begin{array}{l}\text { Raising awareness for looming regime shifts } \\
\text { via participatory approaches and development } \\
\text { of monitoring systems for critical thresholds } \\
\text { like land-use intensity }\end{array}$ \\
\hline Cascading effects & $\begin{array}{l}\text { Link and integrate HNV farmland policies and } \\
\text { management across a broad spectrum of scales and } \\
\text { domains by developing a holistic landscape approach }\end{array}$ & $\begin{array}{l}\text { Fostering integrated cultural landscape } \\
\text { programs and other inclusive initiatives }\end{array}$ \\
\hline $\begin{array}{l}\text { Ecosystem stewardship and } \\
\text { collaboration }\end{array}$ & $\begin{array}{l}\text { Implement governance strategies based on adaptive } \\
\text { management and community-based knowledge leadership }\end{array}$ & $\begin{array}{l}\text { Supporting bridging organizations, e.g., } \\
\text { landcare groups }\end{array}$ \\
\hline Social capital & $\begin{array}{l}\text { Stimulate flexibility, learning, continuous adaptation of } \\
\text { land-use practices, and social networks among land users }\end{array}$ & $\begin{array}{l}\text { Education and awareness raising, participation, } \\
\text { applying proactive and creative approaches } \\
\text { such as scenario exercises }\end{array}$ \\
\hline $\begin{array}{l}\text { Traditional ecological } \\
\text { knowledge }\end{array}$ & $\begin{array}{l}\text { Foster traditional and local knowledge of HNV land-use } \\
\text { systems; consider them complementary to scientific } \\
\text { knowledge in political decision making }\end{array}$ & $\begin{array}{l}\text { Integration of nonscientific knowledge into the } \\
\text { Intergovernmental Platform on Biodiversity } \\
\text { and Ecosystem Services }\end{array}$ \\
\hline
\end{tabular}

fundamental changes. Building resilience through adaptive management should be brought to the fore, stimulating social capital and mainstreaming traditional and local ecological knowledge into HNV-related decision making. Moreover, a resilience-based approach may help redirect the decline of historical landscape structures into creative pathways and reveal ways in which functions fulfilled by "traditional" elements may be integrated into "modern" land use systems, e.g., into emerging energy cropping systems (Plieninger et al. 2006).

However, resilience approaches are not a panacea to the conservation of $\mathrm{HNV}$ farmlands and may imply some shortcomings. In particular, representation of traditional practices, values, or knowledge is often romanticized and undifferentiated (Widgren 2012). Several resilience-based studies depict traditional farming systems as "timeless," and in so doing, they overlook that many of such systems have experienced radical landscape changes in their history (Renes 2011), although the magnitude of such past landscape transformation has certainly been different than that of the current transformations. In addition, many valuable landscapes are not as ancient as commonly perceived. Evidence of relatively "recent" HNV landscapes is available for the orchard meadows (Streuobstwiesen) of southern Germany, originating in the 18th and 19th centuries (Müller 2005); the bocage landscapes of France and England (c. 1500-1800; Antoine 2002, Turner 2006); the Mediterranean dehesas, having spread out mainly from the 18th to the early 20th centuries (Grove and Rackham 2001, Plieninger 2007); and many extensively grazed heathlands in the Netherlands, having been created in the 1650-1900 period (Spek 2004). These cases teach us that, although it is certainly crucial to conserve the remaining HNV landscapes, we need to complement such conservation approaches through a strategy of developing future HNV-oriented land use systems.

Our intention was to explore the potential of resilience thinking for the management of HNV farmland on the basis of specific landscape-level case studies that necessarily remain limited in their explanatory power. The EU encourages its member states to implement HNV approaches in their Rural Development Programmes, and EU-wide identification of HNV farmland is underway (Van Doorn and Elbersen 2012). At the European level, some descriptions of HNV farming systems (Veen et al. 2009, Oppermann et al. 2012) and mapping exercises (Paracchini et al. 2008) have been published. However, scientific evidence on the linkages between agricultural landscapes, farming systems, and biodiversity is surprisingly scant. Therefore, we call for follow-up efforts to build and communicate an evidence basis for HNV farming. Such review should focus both on the Pan-European and the landscape scale and also link up to similar landscape approaches worldwide (Takeuchi 2010). Important key questions include the following: 
- What are the current and future potentials of, and the trade-offs within, HNV farmland to safeguard biodiversity and ecosystem services while allowing for agricultural production?

- What are the driving forces behind land use change in HNV farmland and the impacts of subsequent changes on biodiversity and ecosystem services provision at different temporal and spatial scales?

- How can the resilience of HNV farmland be enhanced so as to avoid regime shifts toward undesired structural or functional states?

- How can adaptive management strategies be designed to restore the natural and social capital of HNV farming systems?

- What institutions and governance structures are most effective in safeguarding the values of HNV farmland?

Responses to this article can be read online at: http://www.ecologyandsociety.org/issues/responses. php/5877

\section{Acknowledgments:}

We acknowledge support from the German Ministry of Education and Research (FKZ01UU 0904) and the European Commission (Project HERCULES, grant agreement no. 603447, FP7-ENV-2013-two-stage). Two anonymous referees provided constructive feedback. The article processing fee was funded by the German Research Foundation (DFG) and the University of Freiburg in the funding program Open Access Publishing.

\section{LITERATURE CITED}

Andersen, E., D. Baldock, H. Bennet, G. Beaufoy, E. Bignal, F. Brouwer, B. Elbersen, G. Eiden, F. Godeschalk, G. Jones, D. McCracken, W. Nieuwenhuizen, M. van Eupen, S. Hennekes, and G. Zervas. 2003. Developing a high nature value area indicator. Final report. European Environment Agency, Copenhagen, Denmark. [online] URL: http://www. ieep.eu/assets/646/Developing_HNV_indicator.pdf

Antoine, A. 2002. Le paysage de l'historien; archéologie des bocages de l'ouest de la France à l'époque moderne. Presses Universitaires de Rennes, Rennes, France.

Baldock, D., and G. Beaufoy. 1993. Nature conservation and new directions in the EC Common Agricultural Policy. Institute for European Environmental Policy, London, UK.
Barthel, S., C. Folke, and J. Colding. 2010. Social-ecological memory in urban gardens-retaining the capacity for management of ecosystem services. Global Environmental Change: Human and Policy Dimensions 20:255-265. http:// dx.doi.org/10.1016/j.gloenvcha.2010.01.001

Beaufoy, G., D. Baldock, and J. Clark. 1994. The nature of farming: low intensity farming systems in nine European countries. Institute for European Environmental Policy, London, UK.

Beaufoy, G., and K. Marsden. 2013. CAP reform 2013. Last chance to stop the decline of Europe's high nature value farming? European Forum on Nature Conservation and Pastoralism, Hamsterley Vale, County Durham, UK. [online] URL: http://www.efncp.org/download/policy-cap-reform-2013. pdf

Berkes, F., J. Colding, and C. Folke. 2000. Rediscovery of traditional ecological knowledge as adaptive management. Ecological Applications 10:1251-1262. http://dx.doi. org/10.1890/1051-0761(2000)010\%5B1251:ROTEKA\%5D2.0. $\mathrm{CO} ; 2$

Bieling, C. 2013. Perceiving and responding to gradual landscape change at the community level: insights from a case study on agricultural abandonment in the Black Forest, Germany. Ecology and Society 18(2): 36. http://dx.doi. org/10.5751/ES-05590-180236

Bignal, E. M., and D. I. McCracken. 1996. Low-intensity farming systems in the conservation of the countryside. Journal of Applied Ecology 33:413-424. http://dx.doi. org/10.2307/2404973

Bürgi, M., A. Straub, U. Gimmi, and D. Salzmann. 2010. The recent landscape history of Limpach valley, Switzerland: considering three empirical hypotheses on driving forces of landscape change. Landscape Ecology 25:287-297. http://dx. doi.org/10.1007/s10980-009-9412-2

Butler, S. J., J. A. Vickery, and K. Norris. 2007. Farmland biodiversity and the footprint of agriculture. Science 315:381-384. http://dx.doi.org/10.1126/science.1136607

Chapin, F. S., G. P. Kofinas, and C. Folke, editors. 2009. Principles of ecosystem stewardship: resilience-based natural resource management in a changing world. Springer, Berlin, Germany.

Cooper, T., K. Arblaster, D. Baldock, M. Farmer, G. Beaufoy, G. Jones, X. Poux, D. McCracken, E. Bignal, B. Elbersen, D. Wascher, P. Angelstam, J.-M. Roberge, P. Pointereau, J. Seffer, and D. Galvanek. 2007. Final report for the study on HNV indicators for evaluation. Contract notice 2006-G4-04. 
Institute for European Environmental Policy, London, UK. [online] URL: http://ec.europa.eu/agriculture/analysis/external/ evaluation/report.pdf

Council of Europe (COE). 2000. European landscape convention. European Treaty Series, No. 176. COE, Florence, Italy.

Crona, B., and J. N. Parker. 2012. Learning in support of governance: theories, methods, and a framework to assess how bridging organizations contribute to adaptive resource governance. Ecology and Society 17(1): 32. http://dx.doi. org/10.5751/ES-04534-170132/

Daniel, T. C., A. Muhar, A. Arnberger, O. Aznar, J. W. Boyd, K. M. A. Chan, R. Costanza, T. Elmqvist, C. G. Flint, P. H. Gobster, A. Grêt-Regamey, R. Lave, S. Muhar, M. Penker, R. G. Ribe, T. Schauppenlehner, T. Sikor, I. Soloviy, M. Spierenburg, K. Taczanowska, J. Tam, and A. von der Dunk. 2012. Contributions of cultural services to the ecosystem services agenda. Proceedings of the National Academy of Sciences of the United States of America 109:8812-8819. http://dx.doi.org/10.1073/pnas.1114773109

Ellis, E. C., and N. Ramankutty. 2008. Putting people in the map: anthropogenic biomes of the world. Frontiers in Ecology and the Environment 6:439-447. http://dx.doi.org/10.1890/070062

Enengel, B., M. Penker, A. Muhar, and R. Williams. 2011. Benefits, efforts and risks of participants in landscape comanagement: an analytical framework and results from two case studies in Austria. Journal of Environmental Management 92:1256-1267. http://dx.doi.org/10.1016/j. jenvman.2010.12.005

European Environment Agency. 2010. Approximate distribution of HNV farmland in EU-27. European Environment Agency, Copenhagen, Denmark. [online] URL: http://www.eea.europa.eu/data-and-maps/figures/approximatedistribution-of-hnv-farmland

European Union (EU). 2006. Council decision of 20 February 2006 on community strategic guidelines for rural development (programming period 2007 to 2013) (2006/144/EC). Official Journal of the European Union, L 55/20, Publications Office of the EU, Luxembourg, Luxembourg.

Farina, A. 2000. The cultural landscape as a model for the integration of ecology and economics. BioScience 50:313-320. http://dx.doi.org/10.1641/0006-3568(2000)050\% 5B0313:TCLAAM\%5D2.3.CO;2

Fischer, J., T. Hartel, and T. Kuemmerle. 2012. Conservation policy in traditional farming landscapes. Conservation Letters 5:167-175. http://dx.doi.org/10.1111/j.1755-263X.2012.00227. $\underline{\mathrm{X}}$
Folke, C. 2004. Traditional knowledge in social-ecological systems. Ecology and Society 9(3): 7. [online] URL: http:// www.ecologyandsociety.org/vol9/iss3/art7/main.html

Folke, C., J. Colding, and F. Berkes. 2002. Synthesis: building resilience and adaptive capacity in social-ecological systems. Pages 352-387 in F. Berkes, J. Colding, and C. Folke, editors. Navigating social-ecological systems: building resilience for complexity and change. Cambridge University Press, Cambridge, UK. http://dx.doi.org/10.1017/CB09780511541957.020

Gee, K., and B. Burkhard. 2012. Offshore wind farming on Germany's North Sea cost: tracing regime shifts across scales. Pages 185-202 in T. Plieninger and C. Bieling, editors. Resilience and the cultural landscape: understanding and managing change in human-shaped environments. Cambridge University Press, Cambridge, UK. http://dx.doi.org/10.1017/ CBO9781139107778.014

Gómez-Baggethun, E., S. Mingorría, V. Reyes-García, L. Calvet, and C. Montes. 2010. Traditional ecological knowledge trends in the transition to a market economy: empirical study in the Doñana natural areas. Conservation Biology 24:721-729. http://dx.doi.org/10.1111/ j.1523-1739.2009.01401.x

Gómez-Baggethun, E., V. Reyes-García, P. Olsson, and C. Montes. 2012. Traditional ecological knowledge and community resilience to environmental extremes: a case study in Doñana, SW Spain. Global Environmental Change 22:640-650. http://dx.doi.org/10.1016/j.gloenvcha.2012.02.005

Grove, A. T., and O. Rackham. 2001. The nature of Mediterranean Europe: an ecological history. Yale University Press, New Haven, Connecticut, USA.

Gunderson, L. H., and C. S. Holling, editors. 2002. Panarchy: understanding transformations in human and natural systems. Island Press, Washington, D.C., USA.

Halada, L., D. Evans, C. Romão, and J.-E. Petersen. 2011. Which habitats of European importance depend on agricultural practices? Biodiversity and Conservation 20:2365-2378. http://dx.doi.org/10.1007/s10531-011-9989$\underline{Z}$

Hernández-Morcillo, M., J. Hoberg, E. Oteros-Rozas, T. Plieninger, E. Gómez-Baggethun, and V. Reyes-García. 2014. Traditional ecological knowledge in Europe: status quo and insights for the environmental policy agenda. Environment 56, in press.

Hersperger, A. M., and M. Bürgi. 2009. Going beyond landscape change description: quantifying the importance of driving forces of landscape change in a Central Europe case study. Land Use Policy 26:640-648. http://dx.doi. org/10.1016/j.landusepol.2008.08.015 
Holling, C. S. 1973. Resilience and stability of ecological systems. Annual Review of Ecology and Systematics 4:1-23. http://dx.doi.org/10.1146/annurev.es.04.110173.000245

Huntington, H. P. 2000. Using traditional ecological knowledge in science: methods and applications. Ecological Applications 10:1270-1274. http://dx.doi.org/10.1890/1051-0761 (2000)010\%5B1270:UTEKIS\%5D2.0.CO;2

Jansen, J., M. Losvik, and P. Roche. 2009. Vulnerability and resilience of cultural landscapes. Pages 55-66 in $\mathrm{K}$. Krzywinski, M. O'Connell, and H. Küster, editors. Cultural landscapes of Europe: fields of Demeter, haunts of Pan. Aschenbeck Media, Bremen, Germany.

Johnson, R. J., J. A. Jedlicka, J. E. Quinn, and J. R. Brandle. 2011. Global perspectives on birds in agricultural landscapes. Pages 55-140 in W. B. Campbell and S. López Ortíz, editors. Integrating agriculture, conservation and ecotourism: examples from the field. Springer, Dordrecht, The Netherlands. http://dx.doi.org/10.1007/978-94-007-1309-3_3

Kenward, R., and R. Sharp. 2008. Use nationally of wild resources across Europe (UNWIRE). Pages 117-123 in B. Manos and J. Papathanasiou, editors. GEMCONBIO: governance and ecosystem management for conservation of biodiversity (EC FP6 Contract\#028827). Aristotle University of Thessaloniki, Thessaloniki, Greece.

Kenward, R. E., M. J. Whittingham, S. Arampatzis, B. D. Manos, T. Hahn, A. Terry, R. Simoncini, J. Alcorn, O. Bastian, M. Donlan, K. Elowe, F. Franzen, Z. Karacsonyi, M. Larsson, D. Manou, I. Navodaru, O. Papadopoulou, J. Papathanasiou, A. von Raggamby, R. J. A. Sharp, T. Söderqvist, A. Soutukorva, L. Vavrova, N. J. Aebischer, N. Leader-Williams, and C. Rutz. 2011. Identifying governance strategies that effectively support ecosystem services, resource sustainability, and biodiversity. Proceedings of the National Academy of Sciences of the United States of America 108:5308-5312. http://dx.doi.org/10.1073/pnas.1007933108

Kinzig, A. P., P. Ryan, M. Etienne, H. Allison, T. Elmqvist, and B. H. Walker. 2006. Resilience and regime shifts: assessing cascading effects. Ecology and Society 11(1): 20. [online] URL: http://www.ecologyandsociety.org/vol11/iss1/ art20/

Knickel, K. 2001. The marketing of Rhöngold milk: an example of the reconfiguration of natural relations with agricultural production and consumption. Journal of Environmental Policy \& Planning 3:123-136. http://dx.doi. org/10.1002/jepp.79

Liu, J., T. Dietz, S. R. Carpenter, M. Alberti, C. Folke, E. Moran, A. N. Pell, P. Deadman, T. Kratz, J. Lubchenco, E. Ostrom, Z. Ouyang, W. Provencher, C. L. Redman, S. H. Schneider, and W. W. Taylor. 2007. Complexity of coupled human and natural systems. Science 317:1513-1516. http://dx. doi.org/10.1126/science.1144004

Lynam, T., W. de Jong, D. Sheil, T. Kusumanto, and K. Evans. 2007. A review of tools for incorporating community knowledge, preferences, and values into decision making in natural resources management. Ecology and Society 12(1): 5. [online] URL: http://www.ecologyandsociety.org/vol12/iss1/ $\underline{\operatorname{art5/}}$

MacDonald, D., J. R. Crabtree, G. Wiesinger, T. Dax, N. Stamou, P. Fleury, J. Gutierrez Lazpita, and A. Gibon. 2000. Agricultural abandonment in mountain areas of Europe: environmental consequences and policy response. Journal of Environmental Management 59:47-69. http://dx.doi.org/10.1006/ jema.1999.0335

Matthews, R., and P. Selman. 2006. Landscape as a focus for integrating human and environmental processes. Journal of Agricultural Economics 57:199-212. http://dx.doi.org/10.1111/ j.1477-9552.2006.00047.x

Millennium Ecosystem Assessment. 2005. Ecosystems and human well-being: synthesis. Island Press, Washington, D.C., USA.

Müller, J. 2005. Landschaftselemente aus Menschenhand. Biotope und Strukturen als Ergebnis extensiver Nutzung. Elsevier, Munich, Germany.

Navarro, L. M., and H. M. Pereira. 2012. Rewilding abandoned landscapes in Europe. Ecosystems 15:900-912. http://dx.doi. org/10.1007/s10021-012-9558-7

Olsson, P., C. Folke, V. Galaz, T. Hahn, and L. Schultz. 2007. Enhancing the fit through adaptive co-management: creating and maintaining bridging functions for matching scales in the Kristianstads Vattenrike Biosphere Reserve, Sweden. Ecology and Society 12(1): 28. [online] URL: http://www. ecologyandsociety.org/vol12/iss1/art28/

Oppermann, R., G. Beaufoy, and G. Jones, editors. 2012. High nature value farming in Europe - 35 European countries, experiences and perspectives. Verlag Regionalkultur, Ubstadt-Weiher, Germany.

O'Rourke, E. 2006. Biodiversity and land use change on the Causse Méjan, France. Biodiversity and Conservation 15:2611-2626. http://dx.doi.org/10.1007/s10531-005-5402-0

O'Rourke, E., and N. Kramm. 2012. High nature value (HNV) farming and the management of upland diversity. A review. European Countryside 4:116-133. http://dx.doi.org/10.2478/ v10091-012-0018-3

Paracchini, M. L., J.-E. Petersen, Y. Hoogeveen, C. Bamps, I. Burfield, and C. van Swaay. 2008. High nature value farmland in Europe. An estimate of the distribution patterns on the basis of land cover and biodiversity data. Office for 
Official Publications of the European Communities, Luxembourg, Luxembourg. [online] URL: http://agrienv.jrc. it/publications/pdfs/HNV Final Report.pdf

Parrotta, J. A., and M. Agnoletti. 2007. Traditional forest knowledge: challenges and opportunities. Forest Ecology and Management 249:1-4. http://dx.doi.org/10.1016/j.foreco.2007.05.022

Pinto-Correia, T., and W. Vos. 2004. Multifunctionality in Mediterranean landscapes - past and future. Pages 135-164 in R. H. G. Jongman, editor. The new dimensions of the European landscape. Springer, Berlin, Germany.

Plieninger, T. 2007. Constructed and degraded? Development and persistence of savanna-like dehesas in two Spanish municipalities. Die Erde 138:223-244.

Plieninger, T., O. Bens, and R. F. Hüttl. 2006. Perspectives of bioenergy for agriculture and rural areas. Outlook on Agriculture 35:123-127. http://dx.doi.org/10.5367/000000006777641624

Plieninger, T., and C. Bieling. 2012. Connecting cultural landscapes to resilience. Pages 3-26 in T. Plieninger and C. Bieling, editors. Resilience and the cultural landscape: understanding and managing change in human-shaped environments. Cambridge University Press, Cambridge, UK. http://dx.doi.org/10.1017/CBO9781139107778.003

Plieninger, T., H. Schaich, and T. Kizos. 2011. Land-use legacies in the forest structure of silvopastoral oak woodlands in the Eastern Mediterranean. Regional Environmental Change 11:603-615. http://dx.doi.org/10.1007/s10113-010-0192-7

Plieninger, T., C. Schleyer, H. Schaich, B. Ohnesorge, H. Gerdes, M. Hernández-Morcillo, and C. Bieling. 2012. Mainstreaming ecosystem services through reformed European agricultural policies. Conservation Letters 5:281-288. http://dx.doi.org/10.1111/j.1755-263X.2012.00240. $\underline{\mathrm{X}}$

Prager, K., and J. Freese. 2009. Stakeholder involvement in agri-environmental policy making - learning from a local-and a state-level approach in Germany. Journal of Environmental Management 90:1154-1167. http://dx.doi.org/10.1016/j. jenvman.2008.05.005

Renes, J. 2011. European landscapes: continuity and change. Pages 117-136 in Z. Roca, P. Claval, and J. Agnew, editors. Landscapes, identities and development. Ashgate, Farnham, UK.

Rescia, A. J., B. A. Willaarts, M. F. Schmitz, and P. A. Aguilera. 2010. Changes in land uses and management in two Nature Reserves in Spain: evaluating the social-ecological resilience of cultural landscapes. Landscape and Urban Planning 98:26-35. http://dx.doi.org/10.1016/j.

landurbplan.2010.07.007
Rotherham, I. D. 2007. The implications of perceptions and cultural knowledge loss for the management of wooded landscapes: a UK case-study. Forest Ecology and Management 249:100-115. http://dx.doi.org/10.1016/j. foreco.2007.05.030

Scheffer, M., and S. R. Carpenter. 2003. Catastrophic regime shifts in ecosystems: linking theory to observation. Trends in Ecology \& Evolution 18:648-656. http://dx.doi.org/10.1016/ j.tree.2003.09.002

Scherr, S. J., and J. A. McNeely. 2008. Biodiversity conservation and agricultural sustainability: towards a new paradigm of 'ecoagriculture' landscapes. Philosophical Transactions of the Royal Society B: Biological Sciences 363:477-494. http://dx.doi.org/10.1098/rstb.2007.2165

Schleyer, C., and T. Plieninger. 2011. Obstacles and options for the design and implementation of payment schemes for ecosystem services provided through farm trees in Saxony, Germany. Environmental Conservation 38:454-463. http://dx. doi.org/10.1017/S0376892911000361

Schultz, L., C. Folke, and P. Olsson. 2007. Enhancing ecosystem management through social-ecological inventories: lessons from Kristianstads Vattenrike, Sweden. Environmental Conservation 34:140-152. http://dx.doi.org/10.1017/ $\underline{\text { S0376892907003876 }}$

Selman, P., and M. Knight. 2006. On the nature of virtuous change in cultural landscapes: exploring sustainability through qualitative models. Landscape Research 31:295-307. http://dx.doi.org/10.1080/01426390600783517

Spek, T. 2004. Het Drentse esdorpenlandschap: een historisch-geografische Studie. Matrijs, Utrecht, The Netherlands.

Takeuchi, K. 2010. Rebuilding the relationship between people and nature: the Satoyama Initiative. Ecological Research 25:891-897. http://dx.doi.org/10.1007/s11284-010-0745-8

Termorshuizen, J. W., and P. Opdam. 2009. Landscape services as a bridge between landscape ecology and sustainable development. Landscape Ecology 24:1037-1052. http://dx.doi.org/10.1007/s10980-008-9314-8

Tscharntke, T., Y. Clough, T. C. Wanger, L. Jackson, I. Motzke, I. Perfecto, J. Vandermeer, and A. Whitbread. 2012. Global food security, biodiversity conservation and the future of agricultural intensification. Biological Conservation 151:53-59. http://dx.doi.org/10.1016/j.biocon.2012.01.068

Tucker, G. M., and M. F. Heath. 1994. Birds in Europe: their conservation status. BirdLife International, Cambridge, UK.

Turner, S. 2006. Medieval Devon and Cornwall: shaping an ancient countryside. Windgather Press, Bollington, UK. 
Van der Stege, C., B. Vogl-Lukasser, and C. R. Vogl. 2012. The role of homegardens in strengthening social-ecological resilience: case studies from Cuba and Austria. Pages 261-282 in $\mathrm{T}$. Plieninger and $\mathrm{C}$. Bieling, editors. Resilience and the cultural landscape: understanding and managing change in human-shaped environments. Cambridge University Press, Cambridge, UK. http://dx.doi.org/10.1017/CBO9781139107778.019

Van Doorn, A., and B. Elbersen. 2012. Implementation of high nature value farmland in agri-environmental policies: what can be learned from other EU member states? Alterra report 2289. Alterra, Wageningen, The Netherlands. [online] URL: http://edepot.wur.n1/200676

Veen, P., R. Jefferson, J. de Smidt, and J. van der Straaten. 2009. Grasslands in Europe of high nature value. KNNV, Zeist, The Netherlands.

Verburg, P. H., D. B. van Berkel, A. M. van Doorn, M. van Eupen, and H. A. R. M. van den Heiligenberg. 2010. Trajectories of land use change in Europe: a model-based exploration of rural futures. Landscape Ecology 25:217-232. http://dx.doi.org/10.1007/s10980-009-9347-7

Walker, B., L. Gunderson, A. Kinzig, C. Folke, S. Carpenter, and L. Schultz. 2006. A handful of heuristics and some propositions for understanding resilience in social-ecological systems. Ecology and Society 11(1): 13. [online] URL: http:// www.ecologyandsociety.org/vol11/iss1/art13/

Widgren, M. 2012. Resilience thinking versus political ecology: understanding the dynamics of small-scale labourintensive farming landscapes. Pages 95-110 in T. Plieninger and C. Bieling, editors. Resilience and the cultural landscape: understanding and managing change in human-shaped environments. Cambridge University Press, Cambridge, UK. http://dx.doi.org/10.1017/CBO9781139107778.008 